\title{
Hubungan Pengetahuan Ibu Mengenai Manajemen Laktasi Dengan Pemberian ASI Eksklusif : Literature Review
}

\author{
Arnis Arifianawati ${ }^{1 *}$, Emi Nurlaela ${ }^{2}$ \\ 1,2 Program Studi SarjanavKeperawatan, Universitas Muhammadiyah PekajanganPekalongan, \\ Indonesia \\ *email : arnis.arifianawati@gmail.com
}

\begin{abstract}
Infant mortality rate is one of the highest problems in the world. One of the causes is infection. Most infant deaths can be prevented by exclusive. The purpose of this study was to determine the relationship between mother's knowledge about lactation management and exclusive breastfeeding through a literature review. This research is a quantitative descriptive type of correlation research. 5 articles use the cross sectional approach. 5 articles use the chisquare statistical test, collecting data using a literature review, accessing Garuda Portal data, 5 articles published in 2-11-2021 by using the keyword : Knowledge, Lactation Management, Exclusi Breastfeeding. The critical study instrument used was using the JBI with 8 questions. The characteristics of respondents in this literature review indude age characteristics in the category of 20-35 years, the category of High School Education, and the category of work. The level of knowledge in the poor category obtained results of $142(45,3 \%)$ and breastfeeding in the category of not giving with results of $172(54,9 \%)$. The results of the analysis using the chi-square test found that there was a relationship with the $p$ value of 0,001 . There is a relationship between knowledge of lactation management and exclusive breastfeeding. The results of the literature review can improve health education about exclusive breastfeeding.
\end{abstract}

Keywords: Exclusive Breastfeeding, Management Lactation, Knowledge.

\begin{abstract}
Abstrak
Angka kematian bayi menjadi salah satu masalah tertinggi di dunia. Salah satu penyebabnya adalah infeksi. Sebagian besar kematian bayi bias dicegah dengan pemberian ASI Eksklusif. Pengetahuan ASI Eksklusif perlu dilakukan penelitian. Tujuan dari penelitian ini adalah untuk mengetahui hubungan pengetahuan ibu mengenai manajemen laktasi dengan pemberian ASI Eksklusif melalui literatur review. Penelitian ini adalah penelitian kuantitatif jenis deskriptif korelasi. Dari 5 artikel yang menggunakan Pendekatan Cross Sectional. Dari 5 artikel menggunakan uji statistic Chi-square, pengumpulan data menggunakan literature review, mengakses data Portal Garuda 5 artikel yang diterbitkan pada tahun 2011-2021. Dengan menggunakan kata kunci : "Pengetahuan, ManajemenLaktasi, Pemberian ASI Eksklusif", Instrument telaah kritis yang digunakan yaitu dengan menggunakan JBI dengan 8 pertanyaan. karakteristikresponden pada literature review ini karakteristik usia masuk dalam kategori 20-35 tahun, kategori Pendidikan Pendidikan SMA, kategori pekerjaan bekerja. Tingkat pengetahuan dalam kategori kurang didapatkan hasil 142 (45,3\%) dan pemberian ASI dalam kategori tidak memberikan dengan hasil 172 (54,9\%). Hasil Analisa menggunakan uji chi-square didapatkan ada hubungan dengan nilai $\mathrm{p}$ value 0,001. Penelitian ini terdapat hubungan antara pengetahuan manajemen laktasi dengan pemberian ASI Eksklusif. Hasil literatur review dapat meningkatkan penyuluhan Kesehatan tentang pemberian ASI secara Eksklusif.
\end{abstract}

Kata Kunci :ASI Eksklusif, ManajemenLaktasi, pengetahuan. 


\section{Prosiding Seminar Nasional Kesehatan 2021 Lembaga Penelitian dan Pengabdian Masyarakat Universitas Muhammadiyah Pekajangan Pekalongan}

\section{Pendahuluan}

Angka kematian bayi menjadi salah satu masalah tertinggi di dunia. Salah satu penyebabnya adalah infeksi. Sebagian besar kematian bayi bias dicegah dengan pemberian ASI Eksklusif. Penyebab kematian bayi baru lahir sampai dengan berumur 6 hari adalah bayi berat badan bayi ketika lahir di bawah normal (21,3 persen), gangguan pernafasan yaitu asfiksia (17,3 persen), respiratory distress of newborn (11 persen) dan sepsis neonatorum 5,9 persen. Penyebab kematian bayi berumur 7- 28 hari tertinggi adalah pneumonia (34,5 persen), penyebab perinatal lainnya $(13,7$ persen), sepsis neonatorum (10,2 persen), kelainan kongenital (8,6 persen), dan penyakit infeksi dan parasit (7,1 persen) (Djaja, dkk, 2012). [1].

Air Susu Ibu (ASI) adalah suatu imulsi lemak dalam larutan protein, laktosa, dan garam-garam organik yang disekresi oleh kedua kelenjar payudara ibu, yang berguna sebagai makanan utama bagi bayi (Haryono, 2014). [2], [4].

Air susu ibu yang diberi secara ekslusif tersebut terutama banyak yang mengandung zat gizi yang sangat bermanfaat buat bayi karena kurang lebih di hari 1-3 air susu ibu mengandung kolostrum. Kolostrum sangat bermanfaat bagi bayi (Widuri, 2013).[3]. Asi Eksklusif adalah pemberian ASI saja tanpa tambahan cairan lain seperti susu formula, jeruk, madu, air teh, air putih dan tanpa tambahan makanan padat seperti pisang, papaya, bubur susu, biscuit, dan nasi tim. Pemberian ASI ini dianjurkan dalam waktu 6 bulan (Haryono, 2014).[2], [4], [6].

Manajemen Laktasi adalah suatu kata tata laksana yang menyangkut laktasi dan penggunaan ASI yang berhasil menyusui untuk menjaga Kesehatan ibu dan bayi. Manajemen ini meliputi suatu persiapan dan Pendidikan penyuluhan ibu, pelaksanaan menyusui dan rawat gabung dan usaha lanjutan perlindungan ibu yang menyusui (Prasetyono, 2012). [5].

Proses menyusui dapat berjalan lancar, maka seorang ibu harus mempunyai keterampilan menyusui agar ASI dapat mengalir dari payudara ibu ke bayi secara efektif. Keterampilan menyusui yang baik meliputi posisi menyusui dan perlekatan bayi pada payudara yang tepat (Haryono, 2014). [2], [4], [6].

Pengetahuan ibu tentang ASI eksklusif dapat mempengaruhi ibu dalam pemberian ASI. Semakin baik pengetahuan ibu mengenai ASI eksklusif, maka seorang ibu akan memberikan ASI eksklusif pada anaknya secara maksimal, begitu juga sebaliknya (Fatimah, 2017). [7], [8].

Tingkat pengetahuan yang tinggi ikut menentukan mudah tidaknya ibu untuk memahami dan menyerap informasi mengenai ASI eksklusif. Semakin tinggi tingkat pengetahuan ibu, maka semakin tinggi pula ibu menyerap informasi tentang ASI eksklusif. Tingkat pengetahuan yang baik dalam memberikan ASI secara eksklusif selama 6 bulan akan bermanfaat untuk pertumbuhan dan perkembangan bayi (Fatimah, 2017). [7], [8].

\section{Metode}

Penelitian ini adalah penelitian kuantitatif jenis deskriptif korelasi. Dari 5 artikel yang menggunakan Pendekatan Cross Sectional. Dari 5 artikel menggunakan uji statistic Chi-square, pengumpulan data menggunakan literature review, mengakses 


\section{Prosiding Seminar Nasional Kesehatan Lembaga Penelitian dan Pengabdian Masyarakat Universitas Muhammadiyah Pekajangan Pekalongan}

data Portal Garuda 5 artikel yang diterbitkan pada tahun 2011-2021. Dengan menggunakan kata kunci : "Pengetahuan, Manajemen Laktasi, Pemberian ASI Eksklusif", Instrument telaah kritis yang digunakan yaitu dengan menggunakan JBI dengan 8 pertanyaan.

\section{Hasil dan Pembahasan}

\section{Hasil}

1. Data Karakteristik Usia Responden

Tabel 3.1 Hasil Literature Review Data Karakteristik Usia Responden

\begin{tabular}{|c|c|c|c|c|c|}
\hline \multirow[t]{2}{*}{ Penulis } & \multirow[t]{2}{*}{ Tahun } & \multirow[t]{2}{*}{ JumlahResponden } & \multicolumn{3}{|l|}{ Usia } \\
\hline & & & Umur/Tahun & $\mathbf{F}$ & $\%$ \\
\hline \multirow[t]{2}{*}{ LusianaGultom } & 2017 & 40 & $16-27$ & 22 & 1,8 \\
\hline & & & $28-40$ & 18 & 9,7 \\
\hline \multirow[t]{2}{*}{ AureliyaHutagaol } & 2018 & 40 & $19-29$ & 33 & 17,8 \\
\hline & & & $30-39$ & 7 & 3,7 \\
\hline \multirow[t]{2}{*}{ DewiSartikaManik } & 2020 & 67 & $20-35$ & 44 & 23,7 \\
\hline & & & $36-45$ & 23 & 12,4 \\
\hline \multirow[t]{2}{*}{ Sri Sumarni } & 2015 & 38 & $24-31$ & 25 & 13,5 \\
\hline & & & $20-35$ & 13 & 7 \\
\hline Jumita & 2020 & NM & NM & NM & NM \\
\hline Total & & & & 185 & 100 \\
\hline
\end{tabular}

Berdasarkan table 3.1 dapatdiketahuibahwausiaibumenyusui yang paling banyakberusia 20-35 adalah 44 responden (23,7\%).

2. Data Karakteristik Pendidikan

Tabel3.2 Hasil Literature Review Data Karakteristik Pendidikan responden

\begin{tabular}{|c|c|c|c|c|c|}
\hline Penulis & Tahun & JumlahResponden & Pekerjaan & $\mathbf{F}$ & $\%$ \\
\hline \multirow[t]{7}{*}{ LusianaGulton } & 2017 & 40 & Karyawan & 12 & 8,1 \\
\hline & & & Guru/Dosen & 2 & 1,3 \\
\hline & & & Bidan/Petugas & 2 & 1,3 \\
\hline & & & Kesehatan & 10 & 6,8 \\
\hline & & & Wiraswasta & 5 & 3,4 \\
\hline & & & PNS & 9 & 6,1 \\
\hline & & & Buruh & & \\
\hline \multirow[t]{2}{*}{ AureliyaHutagaol } & 2018 & 40 & Bekerja & 11 & 7,4 \\
\hline & & & TidakBekerja & 29 & 19,7 \\
\hline \multirow[t]{2}{*}{ DewiSartikaManik } & 2020 & 67 & Bekerja & 46 & 31,2 \\
\hline & & & TidakBekerja & 21 & 14,2 \\
\hline Sri Sumarni & 2015 & 38 & NM & NM & NM \\
\hline Jumita & 2020 & 128 & NM & NM & NM \\
\hline Total & & & & 147 & 100 \\
\hline
\end{tabular}




\section{Prosiding Seminar Nasional Kesehatan Lembaga Penelitian dan Pengabdian Masyarakat Universitas Muhammadiyah Pekajangan Pekalongan

Berdasarkan table 3.2 dapat diketahui bahwa Pekerjaan ibu menyusui paling banyak adalah bekerja 97 responden $(65,9 \%)$, dan yang plaing sedikit adalah tidak bekerja 50 responden (34\%).

3.

Data KarakteristikPekerjaan

Tabel3.3 Hasil Literature Review Data Karakteristikpekerjaanresponden

\begin{tabular}{|c|c|c|c|c|c|}
\hline Penulis & Tahun & JumlahResponden & Pekerjaan & $\mathbf{F}$ & $\%$ \\
\hline \multirow[t]{7}{*}{ LusianaGulton } & 2017 & 40 & Karyawan & 12 & 8,1 \\
\hline & & & Guru/Dosen & 2 & 1,3 \\
\hline & & & Bidan/Petugas & 2 & 1,3 \\
\hline & & & Kesehatan & 10 & 6,8 \\
\hline & & & Wiraswasta & 5 & 3,4 \\
\hline & & & PNS & 9 & 6,1 \\
\hline & & & Buruh & & \\
\hline \multirow{2}{*}{ AureliyaHutagaol } & 2018 & 40 & Bekerja & 11 & 7,4 \\
\hline & & & TidakBekerja & 29 & 19,7 \\
\hline \multirow[t]{2}{*}{ DewiSartikaManik } & 2020 & 67 & Bekerja & 46 & 31,2 \\
\hline & & & TidakBekerja & 21 & 14,2 \\
\hline Sri Sumarni & 2015 & 38 & NM & NM & NM \\
\hline Jumita & 2020 & 128 & NM & NM & NM \\
\hline
\end{tabular}

Berdasarkan table 3.3 dapat diketahui bahwa Pekerjaan ibu menyusui paling banyak adalah bekerja 97 responden $(65,9 \%)$, dan yang pling sedikit adalah tidak bekerja 50 responden (34\%).

4.

Data Tingkat Pengetahuan

Tabel3.4 Hasil Literature Review Data Tingkat PengetahuanResponden

\begin{tabular}{|c|c|c|c|c|c|}
\hline Penulis & Tahun & JumlahResponden & $\begin{array}{c}\text { Tingkat } \\
\text { Pengetahuan }\end{array}$ & $\mathbf{F}$ & $\%$ \\
\hline \multirow[t]{3}{*}{ LusianaGulton } & 2017 & 40 & Baik & 11 & 3,5 \\
\hline & & & Cukup & 13 & 4,1 \\
\hline & & & Kurang & 16 & 5,1 \\
\hline \multirow[t]{2}{*}{ AureliyaHutagaol } & 2018 & 40 & Baik & 37 & 11,8 \\
\hline & & & Kurang & 3 & 0,9 \\
\hline \multirow[t]{2}{*}{ DewiSartikaManik } & 2020 & 67 & Baik & 30 & 9,5 \\
\hline & & & Kurang & 37 & 11,8 \\
\hline \multirow[t]{2}{*}{ Sri Sumarni } & 2015 & 38 & Baik & 21 & 6,7 \\
\hline & & & Kurang & 17 & 5,4 \\
\hline \multirow[t]{3}{*}{ Jumita } & 2020 & 128 & Baik & 20 & 6,3 \\
\hline & & & Cukup & 39 & 12,4 \\
\hline & & & Kurang & 69 & 22,0 \\
\hline Total & & & & 313 & 100 \\
\hline
\end{tabular}




\section{Prosiding Seminar Nasional Kesehatan Lembaga Penelitian dan Pengabdian Masyarakat Universitas Muhammadiyah Pekajangan Pekalongan}

Berdasarkan table 3.4 dapat diketahui bahwa tingkat pengetahuan ibu paling banyak adalah pengetahuan kurang 142 responden (45,3\%) dan yang paling sedikit adalah pengetahuan cukup 52 responden (16,6\%).

5.

Data Pemberian ASI

Tabel 3.5 Hasil Literature Review Data pemberian ASI

\begin{tabular}{|c|c|c|c|c|c|}
\hline Penulis & Tahun & JumlahResponden & Pemberian ASI & $\mathbf{F}$ & $\%$ \\
\hline \multirow[t]{2}{*}{ LusianaGulton } & 2017 & 40 & Eksklusif & 19 & 6,0 \\
\hline & & & TidakEksklusif & 21 & 6,7 \\
\hline \multirow[t]{2}{*}{ AureliyaHutagaol } & 2018 & 40 & Memberikan ASI & 39 & 12,4 \\
\hline & & & $\begin{array}{c}\text { TidakMemberikan } \\
\text { ASI }\end{array}$ & 1 & 0,3 \\
\hline \multirow[t]{2}{*}{ DewiSartikaManik } & 2020 & 67 & Ya & 25 & 7,9 \\
\hline & & & Tidak & 42 & 13,4 \\
\hline \multirow[t]{2}{*}{ Sri Sumarni } & 2015 & 38 & Eksklusif & 23 & 7,3 \\
\hline & & & Non Eksklusif & 15 & 4,7 \\
\hline \multirow[t]{2}{*}{ Jumita } & 2020 & 128 & ASI Eksklusif & 35 & 11,1 \\
\hline & & & $\begin{array}{l}\text { Tidak ASI } \\
\text { Eksklusif }\end{array}$ & 93 & 29,7 \\
\hline Total & & & & 313 & 100 \\
\hline
\end{tabular}

Berdasarkan table 3.5 dapat diketahui bahwa pemberian ASI paling banyak adalah ibu yang tidak memberikan ASI 172 responden $(54,9 \%)$ dan yang paling sedikit adalah ibu yang memberikan ASI Eksklusif 141 responden (45\%).

6.

Data

HubunganPengetahuan

Ibu

TentangManajemenLaktasiDenganPemberian ASI Eksklusif

Tabel 4.6 Hasil Literature Review Hubungan Pengetahuan IbuTentang Manajemen Laktasi Dengan Pemberian ASI Eksklusif

\begin{tabular}{|c|c|c|c|}
\hline Pengetahuan Ibu & Pemberian ASI Eksklusif & Jumlah & \\
\hline TentangManajemenLaktasi & $\begin{array}{l}\text { Tidak ASI } \\
\text { Eksklusif }\end{array}$ & & value \\
\hline
\end{tabular}

\begin{tabular}{llllllll} 
& $\mathbf{N}$ & $\mathbf{\%}$ & $\mathbf{N}$ & $\mathbf{\%}$ & $\mathbf{N}$ & $\mathbf{\%}$ & \\
\hline Baik & 99 & 83,1 & 20 & 16,8 & 119 & 100 & \\
Cukup & 22 & 42,3 & 30 & 57,6 & 52 & 100 & $<0,05$ \\
Kurang & 20 & 14,0 & 122 & 85,9 & 142 & 100 & $(0,001)$ \\
& & & & & & & \\
\hline Jumlah & $\mathbf{1 4 1}$ & $\mathbf{4 5 , 0}$ & $\mathbf{1 7 2}$ & $\mathbf{5 4 , 9}$ & $\mathbf{3 1 3}$ & $\mathbf{1 0 0}$ & \\
\hline
\end{tabular}

Berdasarkan tabel 4.6 dapat diketahui bahwa berdasarkan analisis bivariate dari 5 artikel menunjukkan ada hubungan pengetahuan ibu tentang manajemen laktasi dengan pemberian ASI Eksklusif $p$ value $<0,05(0,001)$. 


\section{Prosiding Seminar Nasional Kesehatan 2021 Lembaga Penelitian dan Pengabdian Masyarakat Universitas Muhammadiyah Pekajangan Pekalongan}

\section{Pembahasan}

1. Karakteristik responden

Berdasarkan literature review terhadap 4 artikel mengenai data karakteristik responden ibu menyusui, usia responden terbanyak yaitu berusia 20 - 35 tahun 44 responden $(23,7 \%)$. Banyaknya responden yang mempunyai pengetahuan kurang tentang ASI Eksklusif. Hal ini dapat disebabkan karena adanya faktor usia responden (Iswari,I. 2018). [9].

Distribusi pendidikan menunjukkan responden terbanyak yaitu Pendidikan SMA 128 responden (64,3\%). Hal ini sejalan dengan penelitian Widdiyanto (2012) dengan hasil yang berpendidikan SMA 11 responden (36,7\%), bahwa Pendidikan responden masih banyak yang mempunyai Pendidikan SMA. Semakin rendah pendidikan semakin rendah kemampuan dasar seseorang dalam berpikir untuk pengambilan keputusan khususnya dalam pemberian susu formula pada bayi $0-6$ bulan (Widdiyanto,S. 2012). [10].

Distribusi Berdasarkan literature review terhadap 3 artikel mengenai data karakteristik responden, pekerjaan terbanyak yaitu paling banyak adalah bekerja 97 responden $(65,9 \%)$ daan yang paaling sedikit adalah tidak bekerja 50 responden (34,0\%). Menurut Danso (2014) ibu yang bekerja mengalami kesulitan dalam memberikan ASI Eksklusif karena harus membagi waktu dengan pekerjaannya, selain itu pengaruh dari anggota keluarga juga mempengaruhi praktik pemberian ASI Eksklusif. Dukungan keluarga sangat penting dalam suksesnya menyusui, terutama untuk ASI Eksklusif (Anggania, 2018). [11].

\section{Tingkat Pengetahuan}

Berdasarkan literature review terhadap 5 artikel mengenai data karakteristik tingkat pengetahuan dengan manajemen laktasi, ibu pengetahuan responden terbanyak yaitu pengetahuan baik 110 responden $(47,4 \%)$ dan yang paling sedikit adalah pengetahuan cukup 37 responden (15,9\%). Hal ini sejalan dengan penelitian yang dilakukan Sari (2011) dengan hasil responden pengetahuan dalam kategori kurang sebanyak $16(45,7 \%)$ pengetahuan yang kurang dikarenakan ibu yang kurang memahami arti pentingnya ASI eksklusif bagi bayi. Wawasan mengenai pentingnya ASI eksklusif dapat diperoleh dari berbagai macam media sperti tabloid atau internet serta buku. Pekerjaan ibu yang sebagian besar sebagai pekerja swasta yaitu sebagai karyawan pabrik dengan tingkat pendidikan yang rendah menyebabkan informasi mengenai ASI eksklusif tidak dapat dipahami dengan baik. Pengetahuan adalah hasil dari "tahu" dan ini terjadi setelah orang melakukan penginderaan terhadap suatu objek tertentu. Penginderaan terjadi melalui panca indra manusia yaitu penglihatan, penciuman, rasa dan raba. Sebagian besar pengetahuan atau kognitif merupakan domain yang sangat penting untuk terbentuknya tindakan seseorang. Perilaku yang didasari oleh pengetahuan akan lebih langgeng dari pada perilaku yang tidak didasari demgan pengetahuan (Sari.I, 2011). [12]. 


\section{Prosiding Seminar Nasional Kesehatan 2021 Lembaga Penelitian dan Pengabdian Masyarakat Universitas Muhammadiyah Pekajangan Pekalongan}

\section{Pemberian ASI}

Berdasarkan literature review terhadap 5 artikel mengenai data karakteristik pemberian ASI diketahui bahwa pemberian ASI paling banyak adalah ibu yang tidak memberikan ASI 172 responden (54,9\%), dan yang paling sedikit adalah ibu yang memberikan ASI 141 responden (45\%). Hal inisejalan dengan penelitian yang dilakukan oleh Elliana (2018) dengan hasil responden yang tidak memberikan ASI secara eksklusif lebih banyak yaitu 43 responden (91,5\%) dibandingkan dengan yang memberikan ASI secara eksklusif sebanyak 4 responden (8,5\%).

Bayi di wilayah kerja puskesmas Sekaran kecamatan Gunungpati kota Semarang sebagian besartidak memberika ASI. Keberhasilan dalam memberikan ASI eksklusif dapat dilakukan salah satunya dengan cara membantu ibu bagaimana cara menyusui yang benar dan cara mempertahankan menyusui meski ibu dipisah dari bayi, membantu ibu menyusui semau bayi ibu tanpa pembatasan terhadap lama dan frekuensi menyusui (Elliana, 2018). [13], [14]. Rendahnya pemberian ASI eksklusif di wilayah kerjapuskesmas sekaran kecamatan Gunungpati kota Semarang karena responden memiliki pengetahuan yang cukup bahkan kurang. Selain itu, disebabkan karena responden bekerja sehingga tidak memiliki waktu untuk memberikan ASI eksklusif kepada bayinya, dukungan keluarga yang diberikan pada ibu kurang, putting susu lecet dan air susu tidak keluar sehingga ibu memberikan susu formula dan makanan padat seperti pisang (Elliana, 2018).[13], [14].

$\mathrm{Hal}$ tersebut sesuai dengan firman-Nya yang tertuang dalam QS. Al-Baqarah ayat 233 yang artinya " Para ibu hendaklah menyusukan anak-anaknya selama dua tahun penuh, bagi yang ingin menyempurnakan penyusuan.

4. Hubungan Pengetahuan Ibu Tentang ASI Eksklusif dengan Pemberian ASI

Eksklusif.

Berdasarkan penelitian yang dilakukan menggunakan literature review dengan jumlah 232 responden didapatkan bahwa sebagian besar responden ada hubungan pengetahuan manajemen laktasi dengan pemberian ASI Eksklusif.

Hasil penelitian dari Dian K (2015) menunjukkan adanya hubungan tingkat pengetahuan ibu tentang manajemen laktasi dengan pemberian ASI Eksklusif di desa bligo kecematan Ngluwar Jawa Tengah.

Hasil penelitian Handayani (2015) hubungan pengetahuan manajemen laktasi dengan perilaku dalam pemberian ASI Eksklusif, yang mendapatkan penelitian pada ibu di desa Kenokorejo Polokarto Sukaharjo dengan hasil $p$ value 0,016 adanya hubungan pengetahuan manajemen laktasi dengan perilaku dalam pemberian ASI Eksklusif.

\section{Kesimpulan}

Data karakteristik responden ibu menyusui berdasarkan umur yaitu ibu menyusui Sebagian besar berusia 20-35 tahun 44 responden (23,7\%). Berdasarkan tingkat pendidikan yang paling banyak yaitu pendidikan SMA 128 responden (64,3\%). Berdasarkan pekerjaan yaitu sebagian besar bekerja 97 reponden (65,9\%).

Berdasarkan tingkat pengetahuan, sebagian besar berpengetahuan kurang 142 responden $(45,3 \%)$. 


\section{Prosiding Seminar Nasional Kesehatan Lembaga Penelitian dan Pengabdian Masyarakat Universitas Muhammadiyah Pekajangan Pekalongan}

Berdasarkan pemberian ASI eksklusif, sebagian besar responden tidak memberikan ASI secara eksklusif 172 responden (54,9\%),

Berdasarkan hubungan pengetahuan manajemen laktasi dengan pemberian ASI eksklusif, 5 artikel penelitian yang dilakukan ada hubungan pengetahuan ibu mengenai manajemen laktasi dengan ASI eksklusi $p$ value 0,001 .

\section{Referensi}

[1] Djaja.S, Ning.S. (2014). Pola Penyebab Kematian Kelompok Bayi dan Anak Balita, Hasil Sistem Registrasi Kematian di Indonesia. Jurnal Ekologi Kesehatan, Volume 13 No 3, 265-272.

[2] Haryono.R, Setianingsih.S. (2014). Manfaat ASI Eksklusif Untuk Buah Hati. Yogyakarta: Gosyen Publishing.

[3] Widuri,H. 2013. ASI Eksklusif Bagi Ibu Bekerja. Yogyakarta. Gosyen Publishing.

[4] Prasetyono.D.S. (2012). Buku Pintar ASI Eksklusif. Jogjakarta. Diva Press.

[5] Fatimah.S, Tria.W.O. (2017). Hubungan Pengetahuan Ibu Tentang Manajemen Laktasi Dengan Pemberian ASI Eksk/usif. Jakarta. Fakultas Ilmu Kesehatan Universitas Islam As-Syafi'iyah Jakarta.

[6] Iswari,I. (2018). Gambaran Pengetahuan Suami Dari Ibu Menyusui 0-6 bulan Tentang ASI Eksklusif. Bengkulu.

[7] Widiyanto.S, Dian.A, Merry.T.A. (2012). Hubungan Pendidikan dan Pengetahuan Ibu Tentang ASI Eksklusif dengan Sikap terhadap Pemberian ASI Eksklusif. Semarang. Jurnal Kedokteran Muhammadiyah, Vol 1, No 1.

[8] Anggania.G.A.T, Pemsi. M. W, Sefti.R. 2018. Hubungan Atatus Pekerjaan Ibu Dengan Pemberian ASI Eksk/usif. Manado. Universitas Sam Ratulangi Manado.

[9] Sari.I, Budi.M, \& Wening.A. (2011). Hubungan Tingkat Pengetahuan Ibu Bekerja Dengan Pemberian ASI Eksklusif. Demak.

[10] Elliana.D, Titik.K, Roifatur.R. (2018). Hubungan Pengetahuan dan Dukungan Keluarga Tentang ASI Eksklusif dengan Pemberian ASI. Semarang. Jurnal Kebidanan, Vol 7, No 2.

[11] Gultom,L. (2017). Hubungan Pengetahuan Ibu Bekerja Tentang Manajemen Laktasi Dan Dukungan Tempat Kerja Dengan Perilaku Ibu Dalam Pemmberian ASI Di Wilayah Kerja Puskesmas Pembantu (Pustu) Amplas Medan. Medan. Jurnal IImiah PANNMED.

[12] Hutagaol.A. (2018). Hubungan Pengetahuan Ibu Tentang Manajemen Laktasi Dengan Pemberian ASI Eksklusif. Prodi S1 Keperawatan, Stikes Imelda.

[13] Manik.D.S, Ade.P.R.S, Saharnauli.J.V.S. (2020). Hubungan Tingkat Pengetahuan Dan Sikap Ibu Tentang Air Susu Ibu Eksklusif Di Wilayah Kerja Puskesmas Pembantu Hutatinggi Kecamatan Parmonangan. Parwonangan. NJM Vol 5, No 2.

[14] Sumarni.S. (2015). Hubungan Pengetahuan Ibu dengan Pemberian ASI Eksklusif Usia>6-12 Bulan. Sumenep. Jurnal Kesehatan. 
Prosiding Seminar Nasional Kesehatan Lembaga Penelitian dan Pengabdian Masyarakat

[15] Jumita. (2020). Hubungan Pengetahuan Dan Dukungan Keluarga Dengan Pemberian ASI Eksklusif Pada Bayi Usia 0-6 bulan Di Wilayah Kerja Puskesmas Ratu Agung Kota Bengkulu. Bengkulu. Journal Of Midwifery Vol 8, No 2. 